\title{
A Novel Capsicum Gene Inhibits Host-Specific Disease Resistance to Phytophthora capsici
}

\author{
Gregory Reeves, Ariadna Monroy-Barbosa, and Paul W. Bosland
}

First and third authors: Department of Plant and Environmental Sciences, New Mexico State University, Las Cruces, NM 88003; and second author: Clause Seed Co., 5820 Research Way, Immokalee, FL 34142.

Accepted for publication 20 December 2012.

\begin{abstract}
Reeves, G., Monroy-Barbosa, A., and Bosland, P. W. 2013. A novel Capsicum gene inhibits host-specific disease resistance to Phytophthora capsici. Phytopathology 103:472-478.

A novel disease resistance inhibitor gene (inhibitor of $P$. capsici resistance $[$ Ipcr] ), found in the chile pepper (Capsicum annuum) variety 'New Mexico Capsicum Accession 10399' (NMCA10399), inhibits resistance to Phytophthora capsici but not to other species of Phytophthora. When a highly $P$. capsici-resistant variety was hybridized with

chile pepper. The $\mathrm{F}_{2}$ population displayed a 3:13 resistant-to-susceptible $(\mathrm{R}: \mathrm{S})$ ratio. The testcross population displayed a 1:1 R:S ratio, and a backcross population to NMCA10399 displayed complete susceptibility. These results demonstrate the presence of a single dominant inhibitor gene affecting $P$. capsici resistance in chile pepper. Moreover, when lines carrying the Ipcr gene were challenged against six Phytophthora spp., the nonhost resistance was not overcome. Therefore, the Ipcr gene is interfering with host-specific resistance but not the pathogen- or microbeassociated molecular pattern nonhost responses.
\end{abstract} NMCA10399, the resultant $F_{1}$ populations, when screened, were completely susceptible to $P$. capsici for root rot and foliar blight disease syndromes, despite the dominance inheritance of $P$. capsici resistance in
Additional keywords: host resistance, susceptibility factor.
Phytophthora capsici is arguably the most destructive pathogen to chile pepper (Capsicum sp.) (6). Though difficult to estimate, annual damage of Phytophthora blight to chile pepper yield world-wide exceeds U.S. \$100 million (3). In the shadow of such losses, control measures are needed to safeguard food production from disease outbreak. Plants have adapted the capability to perceive a danger to their health and respond defensively. Knowledge of plant defenses is important for the development of Capsicum varieties with enhanced resistance to Phytophthora blight.

The best strategy to prevent disease in plants is the development of resistant varieties because it is less expensive, environmentally friendly, and a sustainable alternative to chemical applications such as fungicides (11). In addition, planting diseaseresistant varieties does not require alteration to cultivation practices. Disease resistance manifests itself in two forms: host and nonhost resistance. Nonhost resistance is defined as the resistance shown by a plant species toward many pathogens for which it is not considered to be a host, and it is effective against all known isolates of those given pathogens $(13,26)$. The mechanisms of nonhost resistance are not well understood but likely vary on a case-by-case basis and rely upon one or more mechanisms, such as the strengthening of the plant cytoskeleton to provide a physical barrier or the production of secondary metabolites with antimicrobial activity that present a pre- and post-invasion defense mechanism $(10,12,15,22,26)$.

The second form of resistance is host resistance, which is expressed when a plant that is considered a host can resist

Corresponding author: P. W. Bosland; E-mail address: pbosland@nmsu.edu

* The $\boldsymbol{e}$-Xtra logo stands for "electronic extra" and indicates that Figures 1, 2, and 3 appear in color online.

http://dx.doi.org/10.1094/PHYTO-09-12-0242-R

(c) 2013 The American Phytopathological Society infection of a specific pathogenic strain (19). Race-specific resistance operates within host resistance and is defined as resistance to specific isolates of a pathogen but not to all. This type of resistance is associated with the gene-for-gene mechanism $(7,19)$. Basically, a protein product (effector), produced by an avirulence gene in the pathogen is recognized by a resistance $(R)$ gene in the host. A successful recognition results in the induction of a signal transduction in the host that initiates the host defense responses and the inhibition of pathogen growth (35).

In the Capsicum annuum-P. capsici pathosystem, resistance against $P$. capsici in $C$. annuum is reported as a dominant trait $(24,31,38)$. The inheritance of Phytophthora blight resistance is complex. Depending on the site of infection, different disease syndromes (i.e., root rot, foliar blight, fruit rot, and stem blight) are manifested, each of which requires the presence of a specific $R$ gene for the control of each particular disease syndrome $(31,38)$. In addition, different $R$ genes control the resistant phenotype against different physiological races of $P$. capsici within each disease syndrome (24).

In Capsicum spp., specific $R$ genes for $P$. capsici resistance and their mode of action remain largely unknown (30). To better understand the mode of inheritance for host resistance, a unique $P$. capsici-susceptible accession, 'New Mexico Capsicum Accession 10399' (NMCA10399), was evaluated. When tested against several physiological races of $P$. capsici, only susceptible individuals were obtained in the $F_{1}$ population from the hybridization of NMCA10399 to 'Criollo de Morelos-334' (CM-334), which is the accession most resistant to $P$. capsici known. Thus far, CM334 has displayed resistance to all $P$. capsici isolates $(27,33)$. Because CM-334 has $P$. capsici resistance that is considered dominant (38), the presence of only susceptible individuals from this hybridization with NMCA10399 suggested inhibition of the $P$. capsici resistance mechanism present in CM-334 by a gene or genes that has been provisionally designated "inhibitor of P. capsici resistance" (Ipcr). 
Because the Ipcr gene has been found to cause susceptibility to all isolates of $P$. capsici evaluated to date, it was important for this study to test Ipcr for its influence on nonhost resistance against other Phytophthora spp. This study had two goals: (i) evaluate the mode of inheritance for Ipcr and (ii) characterize Ipcr for its effect on host verses nonhost resistance against different Phytophthora spp.

\section{MATERIALS AND METHODS}

Plant materials. For this study, the $C$. annuum accession CM$334\left(\mathrm{P}_{\mathrm{R}}\right)$ was used as a resistant parent. The inhibitor $C$. annuum accession NMCA10399 $\left(\mathrm{P}_{\mathrm{I}}\right)$ and 'Camelot' $\left(\mathrm{P}_{\mathrm{S}}\right)$ (Seminis Vegetable Seed, Inc., St Louis) were used as susceptible parents. To date, NMCA10399 has been susceptible to all P. capsici isolates tested $(27,32)$. This accession is a landrace known as jalapeno espinalteco, collected near Vera Cruz, Mexico. The commercial bell pepper Camelot, grown in the eastern United States, has been used as a $P$. capsici-susceptible control in previous studies (40).

Three $F_{1}$ populations were developed from the hybridizations of CM-334 $\times$ NMCA10399 $\left(\mathrm{P}_{\mathrm{R}} \times \mathrm{P}_{\mathrm{I}}\right), \mathrm{CM}-334 \times$ Camelot $\left(\mathrm{P}_{\mathrm{R}} \times\right.$ $\left.\mathrm{P}_{\mathrm{S}}\right)$, and NMCA10399 $\times$ Camelot $\left(\mathrm{P}_{\mathrm{I}} \times \mathrm{P}_{\mathrm{S}}\right)$. Individual $\mathrm{F}_{1}$ plants were self-pollinated to obtain $F_{2}$ populations. In addition, $F_{1}$ individuals from the CM-334 $\times$ NMCA10399 hybridization were backcrossed to $\mathrm{P}_{\mathrm{R}}$ and $\mathrm{P}_{\mathrm{I}}$, creating a backcross population ([CM$334 \times$ NMCA10399] $\times$ CM-334) $\left(\mathrm{BC}_{1} \mathrm{P}_{\mathrm{R}}\right)$ and a testcross population $\left(\left[C M-334 \times\right.\right.$ NMCA10399] $\times$ NMCA10399) $\left(\mathrm{BC}_{1} \mathrm{P}_{\mathrm{I}}\right)$.

C. annuum planting. Seed to be inoculated for root rot were planted in 72-celled plastic trays, (T. O. Plastics, Clearwater, MN) and seed to be inoculated for foliar blight were planted in larger 48-celled plastic trays (T. O. Plastics). Trays were filled with a commercial peat moss-vermiculite soil mixture (Sun Gro Rediearth Plug \& Seedling mix; Sun Gro Horticulture, Bellevue, WA). Two seeds per cell were sown. Trays were placed on propagation pads to maintain soil temperature at $28^{\circ} \mathrm{C}$ to promote better germination, watered twice a day, and fertilized with a slowrelease fertilizer (Osmocote 14N-6.2P-11.6K; The Scott MiracleGro Company, Marysville, $\mathrm{OH}$ ). Plants were grown in a climatecontrolled greenhouse maintained at 28 and $18 \pm 6^{\circ} \mathrm{C}$ day and night temperatures, respectively, with a 12 -h photoperiod. When the plants reached the four- to six-true-leaf stage, they were inoculated with Phytophthora spp.

In order to verify the phenotype of each susceptible individual from each $\mathrm{F}_{1}$ population while maintaining the plant for hybridization or self-pollination, individual $F_{1}$ plants were regenerated as cuttings before inoculation. The cuttings were placed under $70 \%$ relative humidity until rooting was evident. Once rooted, the selected plants were transplanted and used for hybridizations or self-pollination to obtain seed for the next generation.

Phytophthora isolates. Six species of Phytophthora were provided by The World Phytophthora Collection, Department of Plant Pathology and Microbiology, University of California, Riverside, and included $P$. cinnamomi-P2444 (isolated from Persea americana), Phytophthora citrophthora-P1163 (isolated from Citrus sp.), P. infestans-P9175 (isolated from Solanum lycopersicum), P. nicotianae-P10116 (isolated from Metrosideros excelsa), $P$. sojae-P7082 (isolated from Glycine max), and $P$. capsici physiological race-1 (American Type culture Collection [ATCC]: MYA-2289) (isolated from C. annuum). P. capsici race- 1 was chosen because of its well-characterized virulence toward C. annuum accessions (31).

To test the effect of Ipcr on race-specific resistance, three additional $P$. capsici races were inoculated on the CM-334 $\times$ NMCA10399 $\left(\mathrm{P}_{\mathrm{R}} \times \mathrm{P}_{\mathrm{I}}\right) \mathrm{F}_{1}$ and $\mathrm{F}_{2}$ populations. These included race-2 (ATCC: MYA-2291), race-12 (not in ATCC but available by request), and race-15 (ATCC: MYA-2339). P. capsici physiological race-2 was chosen because of its aggressive virulence toward $C$. annuum accessions; race- 12 and race- 15 were chosen for their mild virulence toward $C$. annuum accessions. P. capsici physiological races $-1,-2$, and -12 were isolated from $C$. annuum in New Mexico and race- 15 was isolated from C. annuum in New Jersey.

Pathogen growth and inoculation of $C$. annuum plants with P. capsici. A specific growing protocol for each Phytophthora sp. was followed to ensure growth, virulence, and zoospore production. For $P$. capsici, the methodology used by Bosland and Lindsey (4) was followed. To confirm the pathogenicity of the $P$. cinnamomi isolate, avocado fruit were inoculated using the method of Hüberli et al. (14). For P. citrophthora, susceptible tomato ( $S$. lycopersicum) leaves were inoculated using the technique described by Flors et al. (8). For P. infestans, the technique described by Appel et al. (2) for inoculating potato $(S$. tuberosum) tubers was used. The technique described by Widmer et al. (39) was followed for $P$. nicotianae to inoculate susceptible tobacco (Nicotiana benthamiana) plants. Soybean (G. max) hypocotyls were inoculated with the injection method described by Dorrance and Schmitthenner (5) to maintain the $P$. sojae isolate.

To test for the effect of Ipcr on host and nonhost resistance, the six Phytophthora spp. were inoculated following the procedure described by Bosland and Lindsey (4) for root rot screening with an inoculum concentration of 10,000 zoospores/plant, and the procedure of Monroy-Barbosa and Bosland (25) for foliar blight screening with an inoculum concentration of 2,000 zoospores/ plant on $C$. annuum plants. These two inoculum concentrations provide accurate and reliable results-distinguishing susceptible and resistant phenotypes to $P$. capsici in $C$. annuum.

Evaluation of Phytophthora root rot and foliar blight disease syndromes used the disease scales described by Bosland and Lindsey (4) and Monroy-Barbosa and Bosland (25), respectively. For root rot disease, healthy plants with no symptoms (disease scale level 0 to 1 ) were considered resistant, while plants showing slight root darkening to death were considered susceptible (levels 2 to 9) (4). For foliar blight, healthy leaves with no symptoms (level 0) or hypersensitive reaction (HR) (level 1) were considered resistant, while inoculated leaves showing lesions larger than the inoculation disc to complete leaf necrosis (levels 2 to 5) were considered susceptible (25). The total number of resistant and susceptible plants were counted and presented as a resistant-tosusceptible ( $R: S)$ ratio. Parents $\left(\mathrm{P}_{\mathrm{R}}, \mathrm{P}_{\mathrm{I}}\right.$, and $\left.\mathrm{P}_{\mathrm{S}}\right)$ were used as controls for the inoculation tests. The plants were scored 12 days after inoculation for root rot and 4 days after inoculation for foliar blight, when the susceptible controls in each test showed level 9 for root rot and level 5 for foliar blight on each respective disease scale.

Experimental design and statistical analysis. To test for nonhost resistance, groups of 24 plants of each parent $\left(\mathrm{P}_{\mathrm{R}}, \mathrm{P}_{\mathrm{I}}\right.$, and $\mathrm{P}_{\mathrm{S}}$ ) were considered experimental units in a completely randomized design. A single group of each parent was screened for root rot and foliar blight resistance with one of each Phytophthora sp. Each group was inoculated with only one Phytophthora sp. and only for one disease syndrome. The inoculations were replicated three times.

To characterize the inheritance of the Ipcr gene, single plants were considered experimental units in a completely randomized design. Two replicate tests in two different years for root rot and two replicate tests in one year for foliar blight were evaluated. At least 108 individuals were evaluated in each $\mathrm{F}_{2}$ population in order to ensure $99.9 \%$ probability of observing a single segregant individual (23).

Data were analyzed using SAS (version 9.3; SAS Institute, Cary, NC). A $\chi^{2}$ goodness-of-fit test $(\alpha=0.05)$ compared the expected versus the observed segregation (R:S) ratios in all the populations. Expected ratios were based on hypothetical Mendelian segregation ratios where the presence of a single dominant epi- 
static gene is involved. The hypothesis was rejected for a specific segregation ratio for any population with $P$ value $\leq 0.05$. A $\chi^{2}$ test of homogeneity $(P \leq 0.05)$ was used to combine data from replicated tests.

\section{RESULTS}

Genetic characterization of a disease resistance inhibitor gene in NMCA10399. In all inoculation trials, the $P$. capsiciresistant parent (CM-334) always displayed phenotypic resistance; no lesions were observed. The susceptible parents

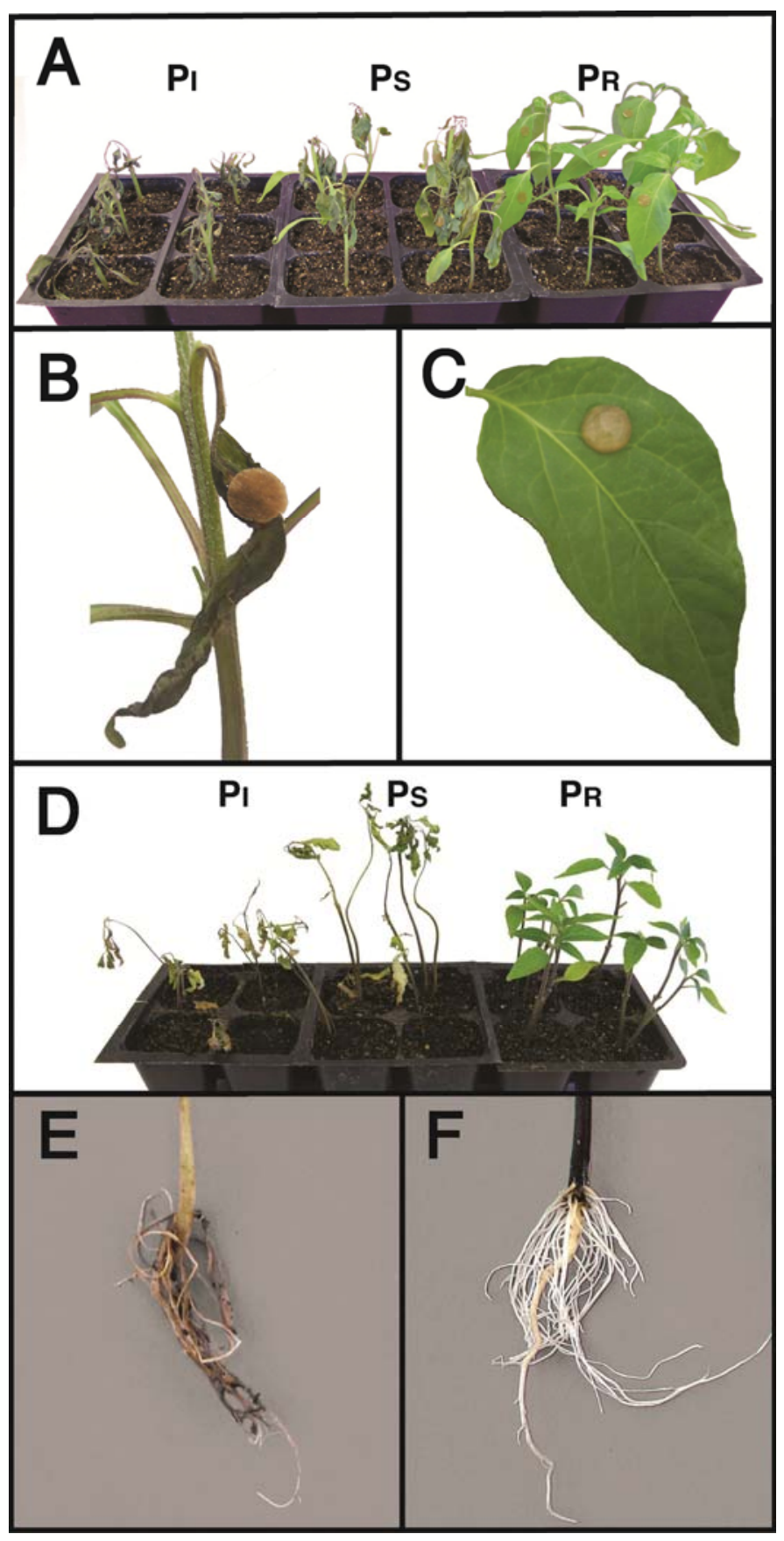

Fig. 1. Symptoms for Phytophthora capsici induced root rot and foliar blight diseases of chile pepper (Capsicum аппиит). A, Resistant and susceptible foliar blight reactions for the inhibitor accession, 'New Mexico Capsicum Accession 10399' (NMCA10399) ( $\left.\mathrm{P}_{\mathrm{I}}\right)$; the susceptible accession, 'Camelot' $\left(\mathrm{P}_{\mathrm{S}}\right)$; and the P. capsici resistant accession, 'Criollo de Morelos-334' $(\mathrm{CM}-334)\left(\mathrm{P}_{\mathrm{R}}\right) 4$ days after inoculation. B, Susceptible foliar blight. C, Resistant foliar blight. D, Resistant and susceptible root rot reactions for $\mathrm{P}_{\mathrm{I}}, \mathrm{P}_{\mathrm{S}}$, and $\mathrm{P}_{\mathrm{R}} 12$ days after inoculation. $\mathbf{E}$, Susceptible root rot. $\mathbf{F}$, Resistant root rot.
(NMCA10399 and Camelot) always scored 9 (plant death) for root rot and 5 (complete leaf necrosis) for foliar blight toward $P$. capsici, as would be expected (Fig. 1). For each population, a $\chi^{2}$ test of homogeneity $(P \leq 0.05)$ indicated data from replicated tests could be combined for simplified data presentation (data not shown).

The CM-334 $\times$ Camelot $\mathrm{F}_{1}$ population displayed complete resistance-showing the dominant inheritance of $P$. capsici resistance for root rot and foliar blight disease syndromes. A segregation ratio of $3: 1(\mathrm{R}: \mathrm{S})$ in the $\mathrm{CM} 334 \times$ Camelot $\mathrm{F}_{2}$ population demonstrated that Camelot is homozygous recessive for the $R$ gene, meaning that it lacks any $R$ genes for $P$. capsici resistance, whereas CM-334 is homozygous dominant for the $R$ genes (Table 1; Fig. 2). The NMCA10399 $\times$ Camelot $F_{1}$ and $F_{2}$ populations were completely susceptible, indicating that neither of the susceptible parents (Camelot and NMCA10399) have any effective $R$ genes against $P$. capsici-induced syndromes with respect to the isolate tested (Table 1; Fig. 2).
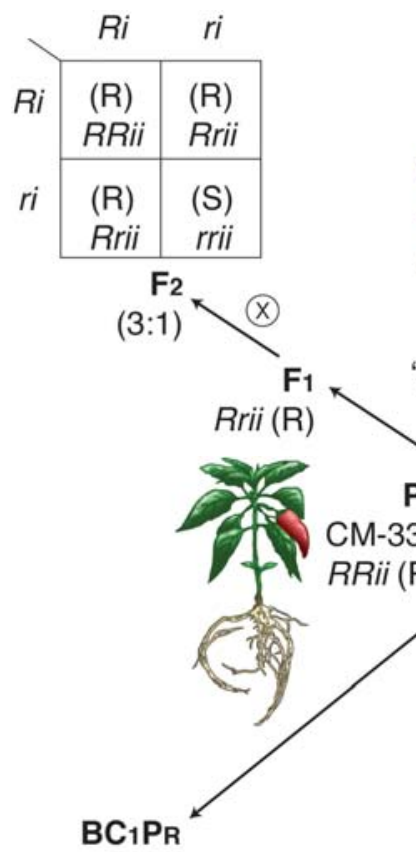

$(1: 1)$

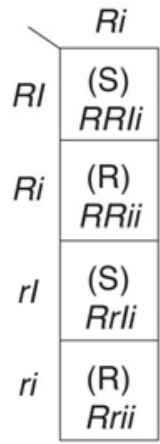

\begin{tabular}{|c|c|c|c|c|}
\hline & RI & $R i$ & $r$ & $r i$ \\
\hline$R I$ & $\begin{array}{c}\text { (S) } \\
R R \|\end{array}$ & $\begin{array}{c}\text { (S) } \\
\text { RRli }\end{array}$ & $\begin{array}{l}\text { (S) } \\
\text { Rrll }\end{array}$ & $\begin{array}{l}\text { (S) } \\
\text { RRIi }\end{array}$ \\
\hline Ri & $\begin{array}{c}\text { (S) } \\
R R l i\end{array}$ & $\begin{array}{c}\text { (R) } \\
R R i i\end{array}$ & $\begin{array}{l}\text { (S) } \\
\text { Rrli }\end{array}$ & $\begin{array}{l}\text { (R) } \\
\text { Rrii }\end{array}$ \\
\hline & $\begin{array}{l}\text { (S) } \\
\text { Rrll }\end{array}$ & $\begin{array}{l}\text { (S) } \\
\text { Rrli }\end{array}$ & $\begin{array}{l}\text { (S) } \\
r r l l\end{array}$ & $\begin{array}{l}\text { (S) } \\
\text { rrli }\end{array}$ \\
\hline & $\begin{array}{c}\text { (S) } \\
\text { RRli }\end{array}$ & $\begin{array}{l}(\mathrm{R}) \\
\text { Rrii }\end{array}$ & $\begin{array}{l}\text { (S) } \\
\text { rrli }\end{array}$ & $\begin{array}{l}\text { (S) } \\
\text { rrii }\end{array}$ \\
\hline
\end{tabular}

\begin{tabular}{|c|c|}
\hline $\begin{array}{l}\text { (S) } \\
\text { rrll }\end{array}$ & $\begin{array}{l}\text { (S) } \\
\text { rrli }\end{array}$ \\
\hline $\begin{array}{l}\text { (S) } \\
\text { rrli }\end{array}$ & \\
\hline
\end{tabular}<smiles>P[PbH]</smiles><smiles>[GeH2]=[GeH2]</smiles>
$\mathrm{F}_{1}$ rrli (S)

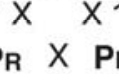

NMCA 10399

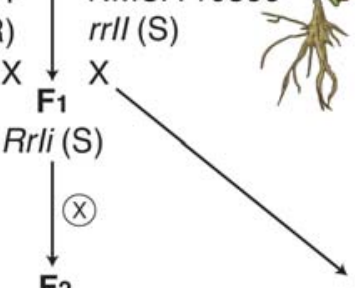

$F_{2}$

$(3: 13)$
$\mathrm{BC}_{1} \mathrm{PI}$

$(0: 1)$
Fig. 2. Inheritance of an inhibitor of Phytophthora capsici resistance (Ipcr) gene in chile pepper (Capsicum апnиит). The Phytophthora capsici-resistant accession, 'Criollo de Morelos-334' (CM-334) ( $\left.\mathrm{P}_{\mathrm{R}}\right)$, was hybridized to P. capsici-susceptible accessions 'New Mexico Capsicum Accession 10399' (NMCA10399) $\left(\mathrm{P}_{\mathrm{I}}\right)$ and 'Camelot' $\left(\mathrm{P}_{\mathrm{S}}\right)$ to generate $\mathrm{F}_{1}$ and $\mathrm{F}_{2}$ populations, respectively. The $\mathrm{CM}-334 \times \mathrm{NMCA} 10399\left(\mathrm{~F}_{1}\right)$ population was backcrossed to the resistant and inhibitor parents to generate $\mathrm{BC}_{1} \mathrm{P}_{\mathrm{R}}$ and $\mathrm{BC}_{1} \mathrm{P}_{\mathrm{I}}$ populations. Resistant-to-susceptible (R:S) phenotypic ratios in the $F_{2}$ and backcross populations are shown in parentheses below. $\mathrm{R}$ and $\mathrm{S}$ represent resistant and susceptible phenotypes, respectively, for both root rot and foliar blight disease syndromes. The $R / r$ alleles are representative of dominant/recessive $R$ genes for root rot $\left(\mathrm{R}_{\mathrm{rr}}\right)$ and foliar blight $\left(\mathrm{R}_{\mathrm{fb}}\right) ; I / i$ are dominant/recessive alleles for Ipcr. 
The CM-334 $\times$ NMCA10399 $\mathrm{F}_{1}$ population displayed complete susceptibility to Phytophthora root rot and foliar blight disease syndromes. The CM-334 $\times$ NMCA10399 $F_{2}$ population displayed a 3:13 (R:S) segregation ratio, indicating that the Ipcr gene has an epistatic dominant effect over the dominant $R$ genes for root rot and foliar blight (Table 1; Fig. 2). After this finding, the CM-334 $\times$ NMCA10399 $\mathrm{F}_{1}$ and $\mathrm{F}_{2}$ populations were separately inoculated with three additional $P$. capsici races for root rot (race-2, race-12, and race-15) to test whether Ipcr can inhibit resistance against other $P$. capsici races. In all cases, the populations behaved the same. The CM-334 $\times$ NMCA10399 $F_{1}$ population showed complete susceptibility and the $F_{2}$ population showed a 3:13 (R:S) ratio when inoculated for all three races (data not shown).

The testcross population, $([\mathrm{CM}-334 \times$ NMCA10399] $\times$ CM334) $\left(\mathrm{BC}_{1} \mathrm{P}_{\mathrm{R}}\right)$, fit the expected ratio of $1: 1(\mathrm{R}: \mathrm{S})$. The backcross population $([\mathrm{CM}-334 \times \mathrm{NMCA} 10399] \times \mathrm{NMCA10399})\left(\mathrm{BC}_{1} \mathrm{P}_{\mathrm{I}}\right)$ displayed complete susceptibility for foliar blight and root rot syndromes (Table 1; Fig. 2).

Nonhost resistance evaluation in NMCA10399. To ensure the virulence of the isolates, the six Phytophthora spp. were inoculated to their respective hosts. All the inoculated hosts showed disease symptoms: $P$. capsici infected the $C$. annuum accessions NMCA10399 and Camelot, P. cinnamomi infected avocado fruit, $P$. citrophthora infected tomato leaves, $P$. infestans infected potato leaves and tubers, $P$. nicotianae infected tobacco plants, and $P$. sojae infected soybean hypocotyls. These results indicate that each Phytophthora sp. was virulent.

The accession CM-334 displayed phenotypic resistance against the six Phytophthora spp. Only when NMCA10399 and Camelot were inoculated with $P$. capsici did they display susceptible root rot and foliar blight disease symptoms. Conversely, these accessions showed no susceptibility in roots or leaves when they were inoculated with the other five Phytophthora spp. (Table 2). Nonhost resistance type I (no visible symptoms) was observed in CM334 under root rot and foliar blight inoculations with the Phytophthora spp. Type II nonhost resistance (associated with rapid localized necrosis) was expressed in the form of HR (Fig. 3) when leaves of NMCA10399 and Camelot plants were inoculated with $P$. nicotianae and $P$. citrophthora (Table 2). These plants had HR lesions only on the inoculated leaves using the MonroyBarbosa and Bosland (25) paper-disc protocol. Plants with HR lesions were maintained for an additional 4 weeks, and the lesions did not expand, nor were any new lesions formed on the inoculated leaf or any other leaf.

\section{DISCUSSION}

Inheritance and molecular analysis of race-specific resistance within $P$. capsici-induced root rot and foliar blight diseases shows that $P$. capsici resistance in $C$. annuum is polygenic. Walker and Bosland (38) inoculated cloned $C$. annuum plants for root rot and foliar blight. Their results demonstrated that both syndromes require the presence of separate $R$ genes in order to be resistant for both syndromes. Ogundiwin et al. (28) supported this claim by their investigation of quantitative trait loci (QTLs) for root rot and foliar blight resistance to find that, although some QTLs were shared for both syndromes, separate QTLs accounted for resistance to root rot and foliar blight. Moreover, the presence of several race-specific $R$ genes is necessary for resistance against

TABLE 2. Phenotypic reaction of the resistant parent 'Criollo de Morelos-334' (CM-334), the inhibitor parent 'New Mexico Capsicum Accession 10399' (NMCA10399), and the susceptible parent 'Camelot' under Phytophthora root rot (Rot) and foliar blight (Blight) disease screening

\begin{tabular}{|c|c|c|c|}
\hline \multirow[b]{2}{*}{ Accession, species ${ }^{\mathrm{a}}$} & \multicolumn{2}{|c|}{ Disease syndromes $^{b}$} & \multirow[b]{2}{*}{ Obs. $^{c}$} \\
\hline & Rot & Blight & \\
\hline \multicolumn{4}{|l|}{ CM-334 } \\
\hline Phytophthora capsici & $\mathrm{R}$ & $\mathrm{R}$ & $\ldots$ \\
\hline P. cinamomi & $\mathrm{R}$ & $\mathrm{R}$ & $\ldots$ \\
\hline P. citrophthora & $\mathrm{R}$ & $\mathrm{R}$ & $\ldots$ \\
\hline P. infestans & $\mathrm{R}$ & $\mathrm{R}$ & $\ldots$ \\
\hline P. nicotianae & $\mathrm{R}$ & $\mathrm{R}$ & $\ldots$ \\
\hline P. sojae & $\mathrm{R}$ & $\mathrm{R}$ & $\ldots$ \\
\hline \multicolumn{4}{|l|}{ NMCA10399 } \\
\hline P. capsici & $\mathrm{S}$ & $\mathrm{S}$ & $\ldots$ \\
\hline P. cinamomi & $\mathrm{R}$ & $\mathrm{R}$ & $\ldots$ \\
\hline P. citrophthora & $\mathrm{R}$ & $\mathrm{R}$ & HR-L \\
\hline P. infestans & $\mathrm{R}$ & $\mathrm{R}$ & $\ldots$ \\
\hline P. nicotianae & $\mathrm{R}$ & $\mathrm{R}$ & HR-L \\
\hline P. sojae & $\mathrm{R}$ & $\mathrm{R}$ & $\ldots$ \\
\hline \multicolumn{4}{|l|}{ Camelot } \\
\hline P. capsici & $S$ & S & $\ldots$ \\
\hline P. cinamomi & $\mathrm{R}$ & $\mathrm{R}$ & $\ldots$ \\
\hline P. citrophthora & $\mathrm{R}$ & $\mathrm{R}$ & HR-L \\
\hline P. infestans & $\mathrm{R}$ & $\mathrm{R}$ & $\ldots$ \\
\hline P. nicotianae & $\mathrm{R}$ & $\mathrm{R}$ & HR-L \\
\hline P. sojae & $\mathrm{R}$ & $\mathrm{R}$ & $\ldots$ \\
\hline
\end{tabular}

a Capsicum annuum accessions and Phytophthora spp.

${ }^{\mathrm{b}} \mathrm{R}=$ resistant phenotype, no visible lesions and $\mathrm{S}=$ susceptible phenotype, visible disease symptoms.

c Observations: HR-L = hypersensitive response observed on leaves during foliar blight screening.

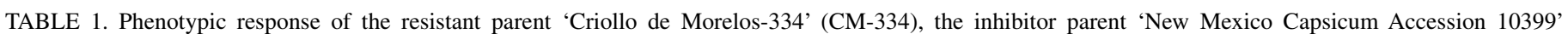

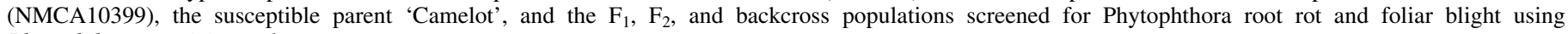
Phytophthora capsici race-1

\begin{tabular}{|c|c|c|c|c|c|c|c|c|c|c|}
\hline \multirow[b]{3}{*}{ Entry } & & & \multicolumn{8}{|c|}{ Disease syndromes $^{\mathrm{a}}$} \\
\hline & \multicolumn{2}{|c|}{ Expected } & \multicolumn{4}{|c|}{ Root $\operatorname{rot}^{b}$} & \multicolumn{4}{|c|}{ Foliar blight $^{\mathrm{c}}$} \\
\hline & Genotype $^{\mathrm{d}}$ & Ratio (R:S)e & $\mathrm{R}$ & $\mathrm{S}$ & $\chi^{2}$ & $P$ value & $\mathrm{R}$ & $\mathrm{S}$ & $\chi^{2}$ & $P$ value \\
\hline CM-334 $\left(\mathrm{P}_{\mathrm{R}}\right)$ & RRii & $1: 0$ & 24 & 0 & - & - & 30 & 0 & - & - \\
\hline NMCA10399 $\left(\mathrm{P}_{\mathrm{I}}\right)$ & $r r I I$ & $0: 1$ & 0 & 24 & - & - & 0 & 30 & - & - \\
\hline 'Camelot' $\left(\mathrm{P}_{\mathrm{S}}\right)$ & rrii & $0: 1$ & 0 & 24 & - & - & 0 & 34 & - & - \\
\hline $\mathrm{P}_{\mathrm{R}} \times \mathrm{P}_{\mathrm{I}}\left(\mathrm{F}_{1}\right)$ & RrIi & $0: 1$ & 0 & 127 & - & - & 0 & 35 & - & - \\
\hline $\mathrm{P}_{\mathrm{R}} \times \mathrm{P}_{\mathrm{S}}\left(\mathrm{F}_{1}\right)$ & Rrii & $1: 0$ & 79 & 0 & - & - & 37 & 0 & - & - \\
\hline $\mathrm{P}_{\mathrm{I}} \times \mathrm{P}_{\mathrm{S}}\left(\mathrm{F}_{1}\right)$ & $r r I i$ & $0: 1$ & 0 & 72 & - & - & 0 & 32 & - & - \\
\hline $\mathrm{P}_{\mathrm{R}} \times \mathrm{P}_{\mathrm{I}}\left(\mathrm{F}_{2}\right)$ & R-ii/--I-/rrii & $3: 13$ & 123 & 556 & 0.04 & 0.84 & 44 & 175 & 0.26 & 0.61 \\
\hline $\mathrm{P}_{\mathrm{R}} \times \mathrm{P}_{\mathrm{S}}\left(\mathrm{F}_{2}\right)$ & $R$-ii/rrii & $3: 1$ & 79 & 32 & 0.87 & 0.35 & 111 & 47 & 1.9 & 0.17 \\
\hline $\mathrm{P}_{\mathrm{I}} \times \mathrm{P}_{\mathrm{S}}\left(\mathrm{F}_{2}\right)$ & $r r--$ & $0: 1$ & 0 & 110 & - & - & 0 & 117 & - & - \\
\hline$\left(\left[\mathrm{P}_{\mathrm{R}} \times \mathrm{P}_{\mathrm{I}}\right] \times \mathrm{P}_{\mathrm{R}}\right)\left(\mathrm{BC}_{1} \mathrm{P}_{\mathrm{R}}\right)$ & $R-I i / R-i i$ & $1: 1$ & 56 & 55 & 0.009 & 0.92 & 35 & 27 & 1.03 & 0.31 \\
\hline$\left(\left[\mathrm{P}_{\mathrm{R}} \times \mathrm{P}_{\mathrm{I}}\right] \times \mathrm{P}_{\mathrm{I}}\right)\left(\mathrm{BC}_{1} \mathrm{P}_{\mathrm{I}}\right)$ & $-r I-$ & $0: 1$ & 0 & 48 & - & - & 0 & 13 & - & - \\
\hline
\end{tabular}

a R and S: number of resistant (R) or susceptible (S) plants. $P$ value, where $\alpha=0.05$.

b Plants were scored using the Bosland and Lindsey (4) protocol.

c Plants were scored using the Monroy-Barbosa and Bosland (25) protocol.

${ }^{\mathrm{d}} \mathrm{R} / \mathrm{r}$ : dominant/recessive resistance gene, I/i: dominant/recessive inhibitor of Phytophthora capsici resistance (Ipcr) gene.

e Resistant-to-susceptible ratio. 
different physiological races of $P$. capsici for both root rot and foliar blight $(24,27,32)$. Troung et al. (34) demonstrated this genefor-gene mechanism of resistance by showing that unique QTLs are required for $P$. capsici race-specific resistance in $C$. annuum. This study of the Ipcr gene did not validate whether or not racespecific resistance operating within resistance to root rot $\left(R_{r r}\right)$ and foliar blight $\left(\mathrm{R}_{\mathrm{fb}}\right)$ are controlled by separate genes but accepts the de facto conclusions of previous research that they are.

The $\mathrm{F}_{1}$ hybridization of the $P$. capsici-resistant parent CM-334 to the susceptible Camelot displayed complete resistance, which is consistent with the dominant inheritance of $P$. capsici resistance with respect to the CM-334 genes (Table 1), establishing CM-334 as dominant and homozygous for resistance to root rot and foliar blight, suggesting $R_{r r} R_{r r} R_{f b} R_{f b} i p c r i p c r$ as the most appropriate genotype for CM-334, whereas Camelot is homozygous recessive, $r_{r r} r_{r r} r_{f b} r_{f b} i p c r i p c r$, for these loci. The CM-334 $\times$ Camelot $\mathrm{F}_{2}$ population ratio of $3: 1(\mathrm{R}: \mathrm{S})$ is indicative of a single $R$ gene that is absent in Camelot, and explains its susceptible phenotype (Table 1). Conversely, total susceptibility obtained in the NMCA10399 $\times$ Camelot $F_{1}$ and $F_{2}$ populations establishes that neither NMCA10399 nor Camelot have any $R$ genes for root rot or foliar blight resistance.

The results from the $F_{1}$ population of the CM-334 $\times$ NMCA10399 hybridization showed a dominant effect of the Ipcr

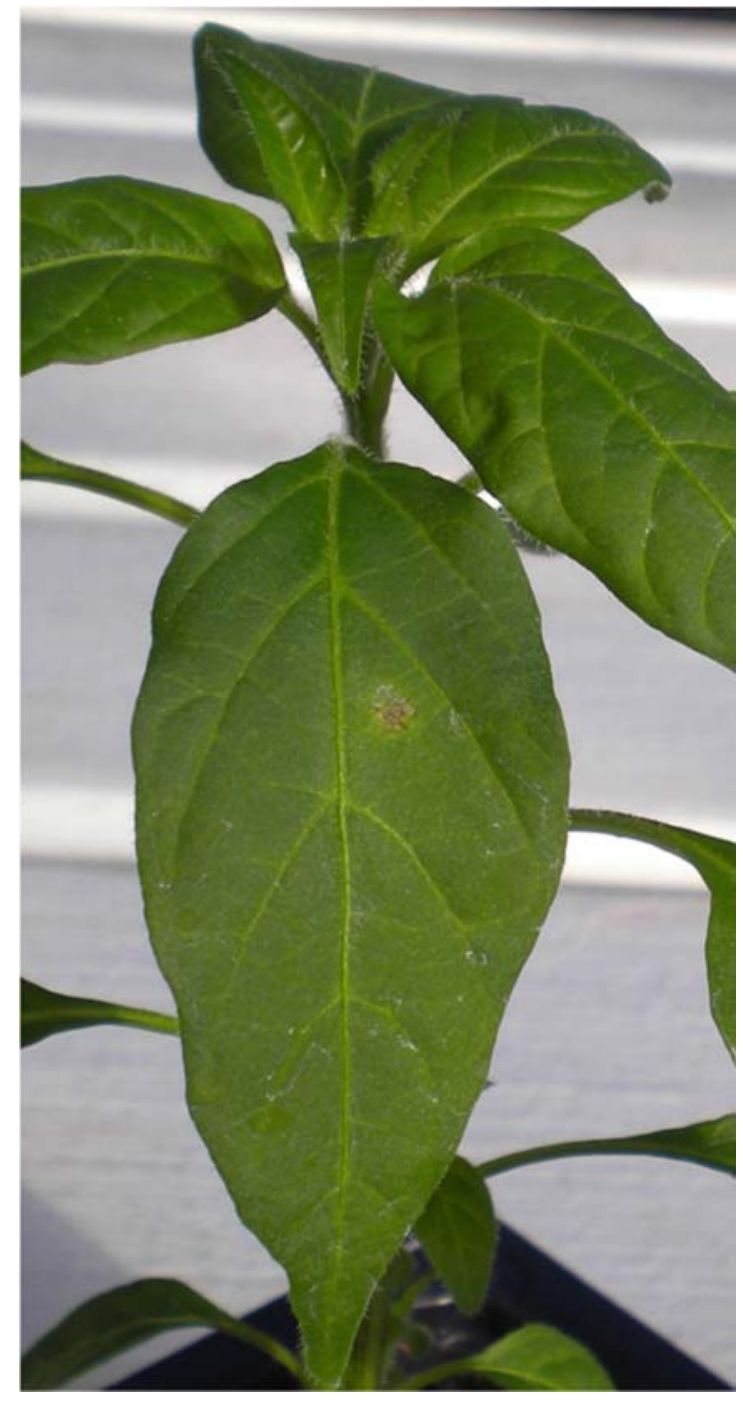

Fig. 3. Hypersensitive response expressed in leaf when the inhibitor accession, 'New Mexico Capsicum Accession 10399' (NMCA10399) ( $\left.\mathrm{P}_{\mathrm{I}}\right)$, was inoculated with Phytophthora nicotianae using the Monroy-Barbosa and Bosland (25) paper-disk technique. gene over the host-specific $R$ genes from CM-334. If the inhibitor gene (Ipcr) is present, then it is expected that the whole population would express susceptibility, displaying a $0: 1(\mathrm{R}: \mathrm{S})$ ratio, with the theoretical genotype for this population being $R_{r r} r_{r r} R_{f b} r_{f b} I p c r i p c r$ (Fig. 2). In the $\mathrm{F}_{1}$ population, it was observed that all the individuals from the CM-334 $\times$ NMCA10399 hybridization were susceptible, which is evidence of the action of Ipcr inhibiting $P$. capsici resistance in $C$. annuum. These individuals have $R$ genes provided by the resistant parent, CM-334; however, the susceptibility of all the individuals in the $F_{1}$ cannot be explained by the absence of $R$ genes but, instead, is explained by the action of an inhibitor gene (Ipcr) interfering with the hostspecific defense mechanism. Thus, a plant can be susceptible for two reasons: lack of $R$ genes or presence of an inhibitor gene.

Similarly, Ipcr could be viewed as a dominant race-nonspecific susceptibility gene. Effectors produced by $P$. capsici, such as RXLR, Crn, or PcNpp effectors, are believed to be critical in the infection process (21). The Ipcr gene may be required for effector sensitivity by being a direct or indirect target, causing effectortriggered susceptibility. The Ipcr gene causes susceptibly for both root rot for several $P$. capsici races and foliar blight syndromes, despite the presence of $R$ genes. Isolation and biochemical analysis of the Ipcr gene are necessary to differentiate whether it functions as a repressor or susceptibility factor.

The 3:13 (R:S) ratio in the CM-334 $\times$ NMCA10399 $\mathrm{F}_{2}$ population when inoculated with four $P$. capsici races for root rot and one for foliar blight confirms the presence of Ipcr and its epistatic effect on $P$. capsici resistance (Fig. 2). The ratio observed in this population establishes that NMCA10399 lacks the $R$ genes for both disease syndromes while being homozygous dominant for the Ipcr-locus, suggesting $r_{r r} r_{r r} r_{f b} r_{f b} I p c r I p c r$ as the most appropriate genotype for NMCA10399. Moreover, the 1:1 (R:S) ratio witnessed in the testcross population ([CM-334 $\times$ NMCA10399] $\times$ CM-334) and total susceptibility seen in the backcross population to the inhibitor parent, ([CM-334 $\times$ NMCA10399] $\times$ NMCA10399) further support the action of a single dominate gene affecting disease resistance to $P$. capsici (Fig. 2).

When nonhost resistance was examined in NMCA10399, it displayed a resistant phenotype against all nonhost Phytophthora spp. tested. This demonstrates that the pathogen- or microbeassociated molecular pattern defense is still functional in NMCA10399 against other Phytophthora spp., despite the presence of Ipcr. Based on these results, Ipcr interferes with the host-specific $R$ genes against $P$. capsici but not nonhost $R$ genes.

An HR in the leaves was observed when the two "susceptible" accessions, NMCA10399 and Camelot, were challenged for foliar blight resistance with $P$. citrophthora and P. nicotianae (Fig. 3), which is characteristic of type II nonhost resistance (16). An HR is a rapid plant cell death defense response induced during penetration of the epidermal cell. It is usually localized to a few plant cells causing cell death-entombing the pathogen from further progression (37). This resistant reaction provides intriguing information because the HR defense mechanism is generally triggered after penetration of the pathogen hyphae. Tobacco plants inoculated with $P$. infestans and $P$. capsici displayed HR when the epidermal and, occasionally, the mesophyll cells were penetrated $(17,37)$. Nonhost plants such as radish (Raphanus sativus), parsley (Petroselinum hortense), and Arabidopsis thaliana inoculated with Phytophthora infestans display HR after penetration (15,37). The expression of HR lesions in NMCA10399 and Camelot suggests that $P$. citrophthora and $P$. nicotianae probably defeated barriers such as callose formation or phytoalexin secretions that are part of nonhost type I resistance. If $P$. nicotianae was able to penetrate mesophyll cells in $C$. annuum plants, this observation would agree with many of the reports that $P$. nicotianae forma specialis can infect Capsicum plants $(1,6,36)$, even though, in New Mexico, isolates 
of $P$. nicotianae are not pathogenic on Capsicum spp. but are found on onion (Allium cepa) (9).

Because genes that partially or completely suppress the activity of $R$ genes are rare-especially dominant genes-the discovery of an inhibitor gene that can completely stop the host resistance mechanism to $P$. capsici is specifically interesting. A suppressor gene $(S)$ that inhibits the expression of $R$ genes to leaf curl virus has been reported in cotton (Gossypium hirsutum) (29). Suppressor genes of stem and leaf rust (Puccinia graminis) resistance in wheat (Triticum turgidum) have been identified, and specifically located on the long arm of chromosome 7D $(18,20)$. Also, suppression of host defense response can occur through the production of inhibitory proteins that target host enzymes (15).

The identification of the dominant Ipcr gene, affecting the dominant resistance of $C$. annuum CM-334 against Phytophthora capsici, is the first of its kind in Capsicum spp. The populations with Ipcr produced for this study were susceptible when inoculated for root rot when treated with four races of $P$. capsici and one race for foliar blight, indicating that Ipcr interferes with tissue- and race-specific resistance for $P$. capsici. Because $P$. capsici resistance to the different disease syndromes is controlled by different $R$ genes, these results suggest that Ipcr is somehow functioning at a "higher" or more fundamental level to affect host resistance.

The discovery of Ipcr can provide new insight into the inheritance and defense mechanisms of the $C$. annuum- $P$. capsici pathosystem. Exploitation of this unique interaction offers a powerful approach to understanding host-pathogen interactions and the mechanisms behind host resistance. The study of the Ipcr gene at the molecular level could provide new information to explain the resistance mechanism leading to a greater understanding of host resistance-including the inheritance, expression, and number of genes involved in resistance against $P$. capsici in $C$. annuum.

\section{ACKNOWLEDGMENTS}

This study is supported, in part, by funds from New Mexico Agricultural Experiment Station, New Mexico State University, Las Cruces.

\section{LITERATURE CITED}

1. Allagui, M. B., and Lepoivre, P. 2000. Molecular and pathogenicity characteristics of Phytophthora nicotianae responsible for root necrosis and wilting of pepper (Capsicum annuиm L.) in Tunisia. Eur. J. Plant Pathol. 106:887-894.

2. Appel, R., Adler, N., and Habermeyer, J. 2001. A method for the artificial inoculation of potato with Phytophthora infestans and polymerase chain reaction assay of latently infected sprouts and stem. J. Phytopathol. $149: 287-292$

3. Bosland, P. W. 2008. Think global, breed local: Specificity and complexity of Phytophthora capsici. In: 19th Int. Pepper Conf. Atlantic City, NJ.

4. Bosland, P. W., and Lindsey, D. L. 1991. A seedling screen for Phytophthora root rot of pepper, Capsicum аппиит. Plant Dis. 75:1048-1050.

5. Dorrance, A. E., Berry, S. A., Anderson, T. R., and Meharg, C. 2008. Isolation, storage, pathotype characterization and evaluation of resistance for Phytophthora sojae in soybean. Plant Health Progress 10:1094.

6. Erwin, D. C., and Ribeiro, O. K. 1996. Phytophthora Diseases Worldwide. American Phytopathological Society, St. Paul, MN.

7. Flor, H. H. 1955. Host-parasite interaction in flax rust-its genetics and other implications. Phytopathology 45:680-685.

8. Flors, V., Miralles, M. C., Gonzalez-Bosch, C., Carda, M., and GarcíaAgustín, P. 2003. Induction of protection against the necrotrophic pathogen Phytophthora citrophthora and Alternaria solani in Lycopersicum esculentum Mill. by a novel synthetic glycoside combined with amines. Planta 216:929-938.

9. French, J. M., Stamler, R. A., and Randall, J. J. 2011. First report of Phytophthora nicotianae on bulb onion in the United States. Plant Dis. 95:1028.

10. Hammond-Kosack, K. E., and Parker, J. E. 2003. Deciphering plantpathogen communications: Fresh perspectives for molecular resistance breeding. Curr. Opin. Microbiol. 14:177-193.
11. Hausbeck, M., and Lamour, K. 2004. Phytophthora capsici on vegetable crops: Research progress and management challenges. Plant Dis. $88: 1292-1303$.

12. Heath, M. 2000. Nonhost resistance and non-specific plant defense. Curr. Opin. Plant Biol. 3:315-319.

13. Heath, M. 2001. Nonhost resistance to plant pathogens: Nonspecific defense or the result of specific recognition events? Physiol. Mol. Plant Pathol. 58:53-54.

14. Hüberli, D., Tommerup, I. C., Dobrowolsky, M. P., Calver, M. C., and Hardy, G. E. 2001. Phenotypic variation in a clonal lineage of two Phytophthora cinnamonni populations from western Australia. Mycol. Res. 105:1053-1064.

15. Kamoun, S. 2001. Nonhost resistance to Phytophthora: novel prospects for a classical problem. Curr. Opin. Plant Biol. 4:295-300.

16. Kamoun, S., Huitema, E., and Vleeshouwers, V. G. 1999. Resistance to Oomycetes: A general role for hypersensitive response? Trends Plant Sci. 4:196-200.

17. Kamoun, S., van West, P., Vleeshouwers, V. G., de Groot, K. E., and Govers, F. 1998. Resistance of Nicotiana benthamiana to Phytophthora infestans by the recognition of the elicitor protein INF1. Plant Cell 10:1413-1425.

18. Kerber, E. R., and Aung, T. 1999. Leaf rust resistant gene Lr34 associated with nonsuppression of stem rust resistance in the wheat cultivar Canthatch. Phytopathology 89:518-521.

19. Király, L., Barna, B., and Király, Z. 2007. Plant resistance to pathogen infection: forms and mechanisms of innate and acquired resistance. $J$. Phytopathol. 155:385-396.

20. Knott, D. R. 2000. Inheritance of resistance to stem rust in medea durum wheat and the role of suppressors. Crop Sci. 40:98-102.

21. Lamour, K. H., Stam, R., Jupe, J., and Huitema, E., 2012. The oomycete broad-host-range pathogen Phytophthora capsici. Mol. Plant Pathol. 13:329-337.

22. Lipka, V., Dittgen, J., Bednarek, P., Bhat, R., Wiemer, M., Stein, M., Landtag, J., Brandt, W., Rosahl, S., Scheel, D., Llorente, F., Molina, A., Parker, J., Somerville, S., and Schulze-Lefert, P. 2005. Pre- and postinvasion defense both contribute to nonhost resistance in Arabidopsis. Science 310:1180-1183.

23. Mainland, G. B. 1951. Muller's method of calculating population sizes for synthesizing new stocks of lines. Heredity 42:237-240.

24. Monroy-Barbosa, A., and Bosland, P. W. 2008. Genetic analysis of Phytophthora root rot race-specific resistance in chile pepper. J. Am. Hortic. Sci. 133:825-829.

25. Monroy-Barbosa, A., and Bosland, P. W. 2010. A rapid technique for multiple-race disease screening of Phytophthora foliar blight on single Capsicum annuum L. plants. HortScience 45:1563-1566.

26. Mysore, K. S., and Ryu, C. 2004. Nonhost resistance: How much do we know? Trends Plant Sci. 9:97-104.

27. Oelke, L. M., Steiner, R., and Bosland, P. W. 2003. Differentiation of race specific resistance to Phytophthora root rot and foliar blight in Capsicum аппиит. J. Am. Soc. Hortic. Sci. 128:213-218.

28. Ogundiwin, E. A., Berke, T. F., Massoudi, M., Black, L. L., Huestis, G., Choi, D., Lee, S., and Prince, J. P. 2005. Construction of 2 intraspecific linkage maps and identification of resistance QTLs for Phytophthora capsici root-rot and foliar-blight diseases of pepper (Cарsicum аппиит L.). Genome 48:698-711.

29. Rahman, M., Hussain, D., Malik, T. A., and Zafar, Y. 2005. Genetics of resistance to cotton leaf curl disease in Gossypium hirsutum. Plant Pathol. 54:764-772.

30. Sanogo, S., and Ji, P. 2012. Integrated management of Phytophthora capsici on solanaceous and cucurbitaceous crops: current status, gaps in knowledge and research needs. Can. J. Plant Pathol. 34:479-492.

31. Sy, O., Steiner, R., and Bosland, P. W. 2005. Inheritance of Phytophthora stem blight resistance as compared to Phytophthora root rot and Phytophthora foliar blight resistance in Capsicum annuиm L. J. Am. Soc. Hortic. Sci. 130:75-78.

32. Sy, O., Steiner, R., and Bosland, P. W. 2008. Recombinant inbred line differential identifies race-specific resistance to Phytophthora root rot in Capsicum annuum. Phytopathology 98:867-870.

33. Thabuis, A., Lefrebvre, V., Bernard, G., Daubeze, A. M., Phaly, T., Pochard, E., and Palloix, A. 2004. Phenotypic and molecular evaluation of a recurrent selection program for a polygenic resistance to Phytophthora capsici in pepper. Theor. Appl. Genet. 109:342-351.

34. Troung, H. T. H., Kim, K. T., Kim, D. W., Kim, S., Chae, Y., Park, J. H., Oh, D. G., and Cho, M. C. 2012. Identification of isolate-specific resistance QTLs to Phytophthora root rot using an intraspecific recombinant inbred line population of pepper (Capsicum апnиит). Plant Pathol. 61:4856.

35. Tyler, B. M. 2002. Molecular basis of recognition between Phytophthora pathogens and their host. Annu. Rev. Phytopathol. 40:137-167.

36. Verma, S., Shyam, K. R., Gupta, S. K., and Sharma, H. R. 2001. Evalua- 
tion of bell pepper (Capsicum аппиит) germplasm for resistance against leaf blight and fruit rot (Phytophthora nicotianae var. nicotianae). Indian J. Agric. Sci. 71:219-221.

37. Vleeshouwers, V. G., van Dooijeweert, W., Govers, F., Kamoun, S., and Colon, L. T. 2000. The hypersensitive response is associated with host and nonhost resistance in Phytophthora infestans. Planta 210:853-864.

38. Walker, S. J., and Bosland, P. W. 1999. Inheritance of Phytophthora root rot and foliar blight resistance in pepper. J. Am. Soc. Hortic. Sci. 124:14-18.
39. Widmer, T. L., Graham, J. H., and Mitchell, D. J. 1998. Histological comparison of fibrous root infection of disease-tolerant and susceptible citrus host by Phytophthora nicotianae and P. palmivora. Phytopathology 88:389-395

40. Wyenandt, C. A., Kline, W. L., Ward, D. L., and Maxwell, N. L. 2009. Cultivar and production system effects on the development of skin separation (or 'silvering') in fruit of bell pepper. Proc. 2nd Int. P. capsici Meet. 2:10-11 